\title{
sciendo ECOLOGICAL INNOVATIONS IN AGRICULTURAL PRODUCTION AS A PRO-DEVELOPMENT FACTOR OF THE ECONOMY
}

doi:10.2478/mape-2018-0076

Date of submission of the article to the Editor: 05/2018

Date of acceptance of the article by the Editor: 07/2018

MAPE 2018, volume 1, issue 1, pp. 603-612

\author{
Prof. dr hab. Magdalena Graczyk \\ Assoc. Prof. Piotr Kułyk \\ PhD., Eng. Leszek Kaźmierczak-Piwko \\ MA. Kukasz Augustowski \\ University of Zielona Góra, Poland
}

\begin{abstract}
The study presents the impact of eco-innovation and policy conducive to the implementation of the principles of sustainable development in agriculture on economic development. The starting point was the analysis of economic growth models and indicating in them the approach to innovation for the implementation of sustainable development. The specifics of eco-innovation in the agricultural sector and their typology have been presented. Due to the complexity of innovative processes and in particular the resulting effects, multi-component measures of innovation and eco-innovation have been discussed. In the last part, using the panel analysis, the effect of eco-innovation in agriculture on socio-economic development at the level of the entire economy has been demonstrated.
\end{abstract}

Keywords: eco-innovations, agricultural production, economy, growth models

\section{INTRODUCTION}

The improvement of the competitive position of modern economies is one of the key areas of interest within economic sciences. The ability to improve competitiveness is the basis for achieving a sustainable path of development and, more broadly, for improving the quality of life of the societies creating them. If we consider the process in question in an intergenerational approach as part of the sustainable development paradigm, it will be conducive to satisfying better the needs of people who are living now as in the future. Therefore, the issue of competitiveness is and will be one of the main motivations of contemporary discourse on shaping the conditions of growth and socio-economic development. The pursuit of being competitive forces the decision-makers creating the framework for the functioning of economic life to constantly search for tools that support and enable the achievement of market advantages in key sectors of the economy. In the literature of the subject, one of the most important mechanisms to improve competitiveness is the ability to create new or significantly improved, and at the same time environmentally friendly, products and technologies, in particular in areas with the highest economic potential. At this point, attention should be paid to eco-innovation, which on the one hand brings tangible economic benefits, and on the other hand does not have a negative impact on the environment, thus contributing to the improvement of the living conditions of societies in the interim period.

In the contemporary world, due to the growing number of population, one of the most important segments of the economy is the agri-food sector, satisfying basic needs and, at the same time, responsible for a significant negative impact on the environment on a global basis. Hence, it can be assumed that the ability to create pro-ecological innovations in this sphere of production will in the coming years significantly affect the development and position that a particular economy will occupy in a globalized market. Therefore, this article refers to the subject of ecological innovations in agriculture as a factor of competitiveness of the economy. The study uses the analysis of the existing literature, the data from official statistics on the issues of eco-innovativeness of business entities was used, and a panel analysis was applied, 
which showed the impact of eco-innovation on the level of development in terms of time and space, which was made the purpose of this article.

\section{INNOVATION AND ECONOMIC POTENTIAL}

Considerations on the impact of innovation in a holistic approach (without separating ecoinnovation) on economic growth can begin with the neoclassical formula of Solow-Swan growth, in which this growth is determined by three basic factors: capital accumulation through savings (investments), increase in labour force resources and technical progress expressed using the so-called rest of Solow (Gust-Bardon, 2012). However, this approach has, as Hayek explained in his work, a static dimension, when in fact the process of shaping innovations takes on a dynamic character in which there are constant changes in technological progress of a discontinuous nature. This model, taking into account the partial substitution between factors of production, places particular emphasis on the accumulation of capital. Excessive simplification, poor explanation of differences between countries as well as exogenous nature of variables and difficulty in explaining differences in capital, the role of knowledge or activities affecting the formation of production factors included in the formula are the basic weaknesses of the neoclassical approach to the formula of growth. According to the research carried out in highly developed countries, technical progress is more than $50 \%$ responsible for economic growth (growth attributed to the rest of Solow). This situation required a better explanation of this factor.

As a result, economists proposed a whole group of endogenous models, in which the assumptions about the occurrence of permanent economies of scale were revoked and the importance of knowledge in the form of human, financial, technological or public capital was included (Uppenberg, 2009; Agenor and Neanidis, 2015). In these processes, the effect of diffusion was taken into account, undermining the possibility of rapid convergence of economic systems, pointing to rather clear difficulties in the process of "catching up" and overcoming structural weaknesses. These models emphasize the importance of economic policy, affecting the amount of R\&D spending, investments in human capital or infrastructure investments contributing to the creation of a specific stream of innovation. In this process, a particular role is also attributed to positive externalities, the accumulation of knowledge that creates a stable base for long-term economic growth and development. Many subsequent empirical studies proved that the level of technological innovations significantly contributes to economic performance, especially at the level of the company, economic sectors or entire countries (Wong et al., 2005).

The research conducted in this area also analysed the relationship between innovation and productivity at the enterprise level. These studies met with "mixed" success. On the basis of the results, it was usually stated that research and development play an important role, but the scope of such research was often limited to a small number of companies or to specific innovations. Modern models indicate the role of innovation as a key factor in supporting economic growth. Originally, a model was developed in which the increase in innovativeness and innovation during the analysis period were two independent variables expressed as the number of patent applications and their growth rate. After the evaluation, a set of socioeconomic factors was introduced, which may have an equal impact on the rate of economic growth. The model's character was log-log, and the impact on GDP growth was to be explained by the number of patent applications, the rate of their growth, the level of employee skills, the situation on the labour market and the economic structure available in the region. The aim of this model, however, was not to capture all the factors conditioning the volatility of GDP growth (Bilbao-Osorio and Rodríguez-Pose, 2004). The research on innovation has also contributed to attempts to explain the relationship between the level of innovation and competitiveness in non-linear models (Aghion et al., 2005). A lot of attention in the scientific discourse was also devoted to the empirical definition of endo- and exo-determinants of introducing ecological 
innovations in enterprises that generate a triad of social, economic and environmental benefits to the economic environment (Kaźmierczak-Piwko, 2011).

Currently, the subject of competitiveness and innovation is very wide. Numerous institutions publish competitiveness indicators for economies at various levels of economic development. However, it should be remembered that innovation is only one of the components affecting a particular economy. The difficulty of capturing all the variables that would describe a "complete model" seems to be still the subject of discussions and disputes.

PROECOLOGICAL INNOVATIVENESS OF THE AGRICULTURAL SECTOR Taking into consideration the ecological innovativeness of the agricultural sector as a factor of competitiveness of the economy, it is worth first defining the term eco-innovation. As noted by Graczyk and Kaźmierczak-Piwko (2012) "The basic taxonomy most often distinguishes three groups of eco-innovations. The first group are low-emission environmental technologies, the second eco-efficiency innovations, and the third group includes system innovations. Their common feature is the orientation to reducing the negative impact on the environment, however, in terms of impact categories, they often differ from each other quite significantly. Therefore, by defining them in a general way, it can be assumed that eco-innovation is above all activities aimed at improving the relation between the enterprise and the environment, which simultaneously generate economic and social benefits." It is worth noting that if it is possible to pro-ecologically improve the production process or introduce a new, more environmentally friendly product to the market, which will bring at the same time future profits, then producers will be willing to pay for such eco-innovation. The economic and scientific capacities on the supply side of eco-innovation, necessary to determine real actions for the development of the agricultural sector depend on investments in basic and applied research and development. If there are appropriate incentives, the market will respond to the demand for eco-innovation by providing new and improved processes and products. Based on the assumption that the market left to itself will show certain unreliability, it can also be assumed that individuals may not be willing to invest in research. This observation has increased the importance of public investment in R\&D projects in agriculture (Moschini, 2001), which launch private investments (multiplier effects). The analysis of the macroeconomic environment of agriculture and its impact on the entire economy gradually grew in significance. In these studies, the problem of external effects and public goods created by agriculture was increasingly taken into account (Kułyk, 2013), increasing the impact of innovation in this sector of the economy. In the case of eco-innovation implementation, external effects take the form of a triad of external benefits: social, economic and environmental generated due to the implementation of pro-ecological innovative solutions on the market (Fig. 1).

The agricultural production process can be presented as a continuous coordination of a wide and flexible range of production factors that affect economic growth. The improvement of the quality of production factors associated with the accumulation of knowledge becomes the focus of scientific research in the current conditions. For a long time, agricultural producers have tried to identify limiting growth factors and develop new farming methods to exceed known production boundaries. Targeting technological changes in agricultural production only to maximize productivity growth only led to periodic improvement of the economic situation of business entities, but as a result of changes in price relations, this effect was relatively quickly disappearing (as a result of a technological treadmill (Reardon et al., 2017). 
EXO-DETERMINANTS

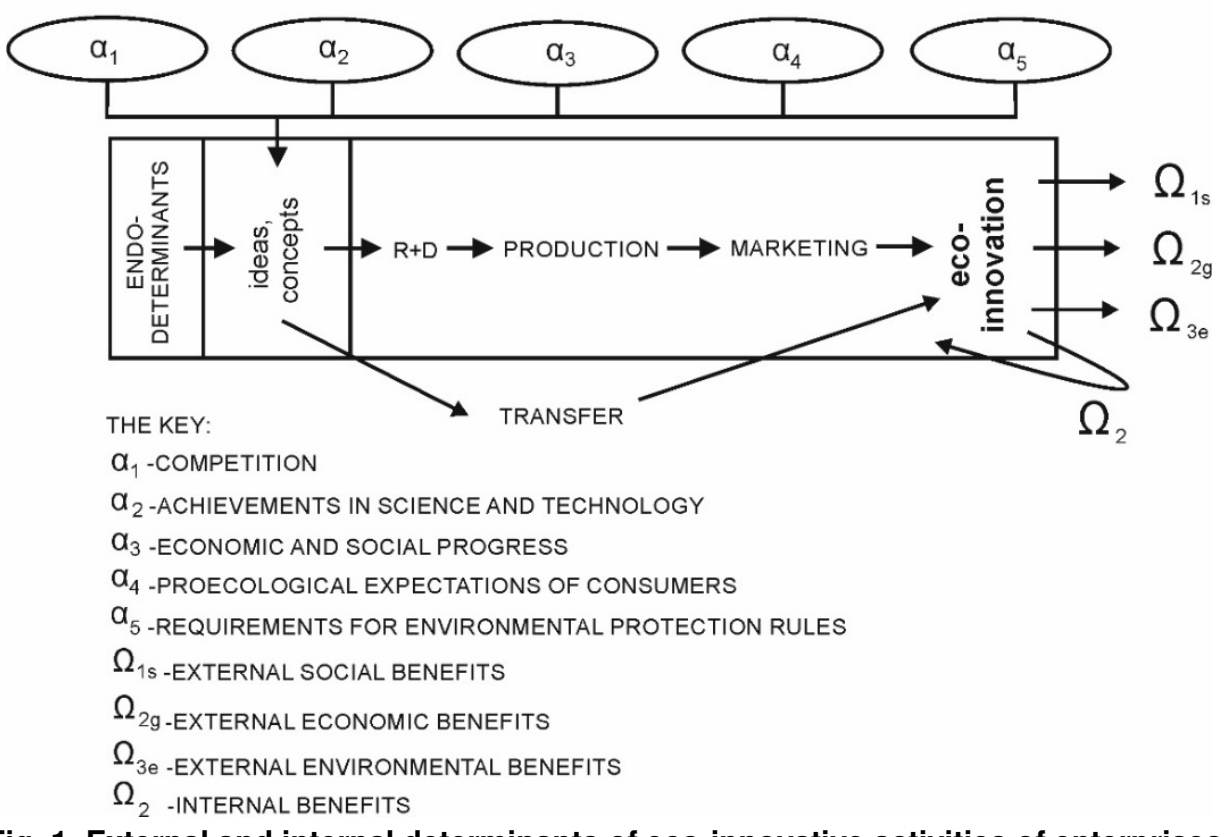

Fig. 1. External and internal determinants of eco-innovative activities of enterprises. Source: (Kaźmierczak-Piwko, 2012).

Moreover, negative external effects of an environmental or social nature were often revealed. In the aftermath of the "green revolution" pro-ecological technological innovations appeared, in the field of water management, mechanization, fertilizers and new plant varieties. These technologies and the use of external input factors caused later improvement of other growth factors and increase agricultural production efficiency. At present, a process is underway in which the role of these growth factors has reduced the role within agricultural practices due to the introduction of increasingly widespread sustainability criteria. Such an approach affects changes in production processes and introduces additional costs (Stuiver et al., 2004). All these factors affect the shaping of ecological innovations in agriculture as well as the creation of smart specializations to improve competitiveness (Szostak, 2015). Thanks to the combination of the results of scientific research, diffusion of innovation and support through the public sector, it has been possible to maintain the growth of agricultural production while limiting adverse effects (Delmer, 2005). As Mirkowska points out, the impact of innovation on the functioning of business entities is manifold and concerns both the volume of sales and market share as well as changes in efficiency and effectiveness. Significant effects include changes in competitiveness and total productivity of production factors (TFP), diffusion of knowledge resulting from innovation at the level of companies, as well as an increase in the amount of knowledge flowing in networks of connections. In addition, the increase in production efficiency creates an opportunity to develop a new product, and new organizational practices can increase the company's ability to acquire and create new knowledge, used to develop further innovations (Mirkowska, 2010). Implementation of innovations in agricultural production is also necessary to meet the needs related to food safety and also helps meet the challenges of sustainable development (Kałuża and Ginter, 2014). The lack of innovative solutions may result in deepened environmental degradation together with the increase in agricultural production resulting from the increase in global demand (Giejbowicz and Chlebicka, 2012). All these factors and the results of domestic and foreign research confirm the need to implement eco-innovations in the agricultural sector. It should be noted that the definition of innovation is recognized differently by different authors, evaluating it from the point of view of research or practice. 
According to the Oslo textbook, innovation is the implementation of a new or significantly improved product (product or service) or process, a new marketing method or a new organizational method in business practice, workplace organization or relations with the environment. The literature is rich in broad typologies of innovation. For the purposes of this publication, they were grouped by type for agricultural activity (Table 1).

Table 1

Types of innovations in farms.

\begin{tabular}{|c|c|c|}
\hline $\begin{array}{c}\text { Type of } \\
\text { innovation }\end{array}$ & Actions & Possible effect of innovation \\
\hline \multirow[t]{4}{*}{ Economic } & $\begin{array}{l}\begin{array}{l}\text { Creating new sales or distribution } \\
\text { channels }\end{array} \\
\end{array}$ & Independence from intermediaries \\
\hline & Improving marketing & Direct sales increase, higher prices for products sold \\
\hline & Creating purchase groups & $\begin{array}{l}\text { Increased negotiating possibilities, shortening the } \\
\text { food chain }\end{array}$ \\
\hline & $\begin{array}{l}\text { Use of renewable energy sources, } \\
\text { collective heating of households }\end{array}$ & $\begin{array}{l}\text { Reduction of energy costs, energy independence } \\
\text { and environmental protection }\end{array}$ \\
\hline \multirow[t]{4}{*}{ Social } & $\begin{array}{l}\text { Building new links between producers } \\
\text { and between producers and } \\
\text { consumers }\end{array}$ & $\begin{array}{l}\text { Shortening the food chain, increasing sales } \\
\text { opportunities }\end{array}$ \\
\hline & $\begin{array}{l}\text { Raising consumer awareness of good } \\
\text { eating habits }\end{array}$ & $\begin{array}{l}\text { Increased sales of high quality agricultural and food } \\
\text { products }\end{array}$ \\
\hline & Farmer as an energy producer & $\begin{array}{l}\text { Energy independence, the possibility of obtaining } \\
\text { additional income }\end{array}$ \\
\hline & $\begin{array}{l}\text { Active participation of farmers in the life } \\
\text { of the region }\end{array}$ & $\begin{array}{l}\text { Groups or associations created can have an impact } \\
\text { on what is happening in the farmers' environment }\end{array}$ \\
\hline \multirow[t]{2}{*}{ Organizational } & $\begin{array}{l}\text { Introduction of new ways to manage } \\
\text { production or sales }\end{array}$ & $\begin{array}{l}\text { More opportunities to sell products, increase } \\
\text { revenues, reduce production costs }\end{array}$ \\
\hline & Changing the organization of work & Saving time and costs \\
\hline \multirow[t]{2}{*}{ Technological } & $\begin{array}{l}\text { New products, crops, agrotechnics, } \\
\text { change in sown structure }\end{array}$ & Increase of production efficiency, increase of income \\
\hline & $\begin{array}{l}\text { New technology for the use of biomass, } \\
\text { energy production on the farm }\end{array}$ & Environmental protection, reduction of energy costs \\
\hline
\end{tabular}

Source: (Tabaka, 2015).

One of the most important types of eco-innovation are technological innovations, thanks to which it is possible to launch new products on the market, change of agrotechnology or the possibility of producing energy on farms. At the level of an agricultural enterprise, different types of technology investments can be distinguished. The first type are capital investments that are conducive to efficiency (computer hardware, software, systems, variable speed technology, sensors, a precise GPS system, etc.). The second type is investments in services that provide useful information (e.g. remote sensing). The third type is knowledge about agriculture and investments in human capital, which involve the creation of highly localized practical knowledge for a specific farm or farming environment (optimal seeding, nutrient and pest management, animal feeding, etc.). These investments consist in collecting data, analysed in order to generate recommendations for farms. These investments in knowledge are made at the local level, and consultants work with farm managers (van Es and Woodard, 2017). Polish regional studies have also confirmed that the innovation of farms depends on the education of farmers and their personality traits (Górka and Ruda, 2012).

\section{ENVIRONMENTAL MEASURES OF INNOVATIVENESS AND COMPETITIVENESS OF ECONOMY}

Operationalization of the problem of separating and assessing innovativeness and competitiveness of the entire economy and its individual segments requires building a specific set of measures. Complexity as well as the mentioned ambiguity in defining the matter under consideration requires the use of complex multicomponent measures. One of the measures of eco-innovation applied in the European Union is the eco-innovation index aimed at capturing 
various aspects of eco-innovation through the use of 16 indicators grouped into five thematic areas:

1. expenditure on ecological innovations including investments (financial or human resources), the purpose of which is to initiate eco-innovation activities,

2. eco-innovation activities illustrating the extent to which companies are active in the field of ecological innovations in a particular country,

3. eco-innovation results, quantifying the results of activities in the field of eco-innovation in terms of patents, scientific literature and media contribution,

4. resource efficiency, eco-innovation implementation, efficiency in the context of resource efficiency (resources, energy, water) in a particular country and the intensity of greenhouse gas emissions,

5. socio-economic results, illustrating to what extent the results of eco-innovation generate positive results in social aspects (employment) and economic aspects (turnover, export).

This indicator divides countries into three groups (EU Eco-Innovation Index, 2016):

1. Leaders of eco-innovations that achieve significantly higher results than the EU average;

2. "Medium-eco-innovative", with assessments at the EU average level;

3. Catching countries in the field of eco-innovations with efficiency less than or equal to $85 \%$ compared to the EU average.

In 2016, Poland was in the back of European countries in terms of ecological innovations measured by the eco-innovation ratio. It was therefore classified into the so-called groups of catching-up countries (Fig. 2).

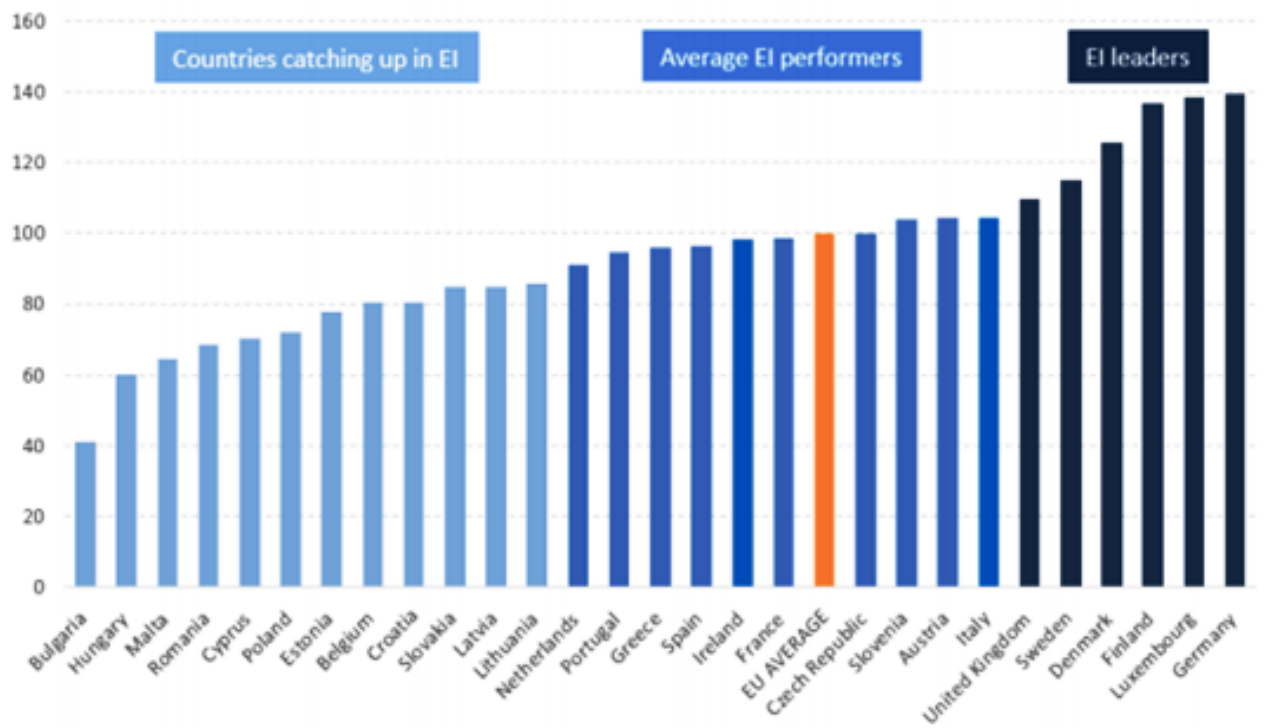

Fig. 2. Eco-innovativeness of European countries in 2016.

Source: (Giljumet et al., 2017).

Leading countries included Germany and Finland, which were also examined in terms of two other indicators. The study uses two indicators: $\mathrm{GCl}$ and $\mathrm{Cll}$, and also takes into account the level of GDP per capita (expressed in USD). The GCI index (Global Competitiveness Index) is one of the most commonly used indices, the purpose of which is to measure the international competitive ability of countries (Szamrej-Baran, 2012). Due to the high popularity, this index is often used in scientific research. It is found, among others, in the analysis of Direct Foreign Investment relationships on the Polish labour market in the time of economic crisis (Augustowski and Sługocki, 2016). This index consists of 3 sub-indexes (basic requirements, efficiency enhancers and efficiency and development factors) in which 12 pillars were included (Tab. 2). 
Table 2

Division of the $\mathrm{GCl}$ index into sub-indices and pillars.

\begin{tabular}{|c|c|c|}
\hline \multicolumn{3}{|c|}{ GCl } \\
\hline $\begin{array}{l}\text { Sub-index: Basic } \\
\text { requirements }\end{array}$ & Sub-index: Efficiency enhancers & $\begin{array}{l}\text { Sub-index: Factors of } \\
\text { innovativeness and development }\end{array}$ \\
\hline Pillar 1. Institutions & $\begin{array}{l}\text { Pillar 5. Higher education and professional } \\
\text { improvement }\end{array}$ & Pillar 11. Business sophistication \\
\hline Pillar 2. Infrastructure & Pillar 6. Efficiency of the goods market & Pillar 12. Innovativeness \\
\hline $\begin{array}{l}\text { Pillar 3. Macroeconomic } \\
\text { environment }\end{array}$ & Pillar 7. Efficiency of the labour market & \\
\hline \multirow[t]{3}{*}{$\begin{array}{l}\text { Pillar } 4 . \text { Health and basic } \\
\text { education }\end{array}$} & Pillar 8. Development of the financial market & \\
\hline & Pillar 9. Technological preparation & \\
\hline & Pillar 10. Market size & \\
\hline
\end{tabular}

Source: Own study based on: (The Global Competitiveness Report 2015-2016 and World Economic Forum 2013-14; 2014-15).

The index 6.08 - "agricultural policy costs" to assess this policy in a particular country is taken as a measure of competitiveness. This ratio is 1 , when excessively onerous costs for the economy are assessed and the value of 7 , when appears well balances the interests of taxpayers, consumers and producers. The second Gll index (Global Innovation Index) - a global innovativeness indicator provides detailed data on the innovation performance of 127 countries and economies around the world. Its 81 indicators examine a broad vision of innovation, including the political environment, education, infrastructure and business sophistication. The sub-pillar indicator 3.3 - "sustainable ecological development" was selected for the assessment. Due to the breadth of data, Poland and 5 developed countries were selected for the years 2013-2017 (Tab. 3).

Table 3

GCl, GIl and GDP in selected countries in 2013-2017.

\begin{tabular}{|c|c|c|c|c|c|c|c|c|c|}
\hline & \multicolumn{3}{|c|}{ Poland } & \multicolumn{3}{|c|}{ Switzerland } & \multicolumn{3}{|c|}{ Germany } \\
\hline & GII & $\mathrm{GCl}$ & GDP & GII & $\mathrm{GCl}$ & GDP & GII & $\mathrm{GCl}$ & GDP \\
\hline 2013 & $37.5(42)$ & $3.6(97)$ & 24423 & $61(5)$ & $3.8(75)$ & 60109 & $41.4(30)$ & $4(58)$ & 45232 \\
\hline 2014 & $44.5(43)$ & $3.6(90)$ & 25288 & $68.4(3)$ & $3.8(68)$ & 61902 & $52.2(21)$ & $4.2(31)$ & 47092 \\
\hline 2015 & $44.7(46)$ & $3.5(95)$ & 26271 & $67.1(2)$ & $3.7(74)$ & 63648 & $52.1(23)$ & $4.3(27)$ & 47811 \\
\hline 2016 & $46.3(49)$ & $3.5(91)$ & 27058 & $65.6(3)$ & $3.8(61)$ & 63889 & $50.8(39)$ & $4.5(20)$ & 48859 \\
\hline \multirow[t]{3}{*}{2017} & $50.3(45)$ & $3.6(77)$ & $x$ & $70.1(2)$ & $3.6(85)$ & $x$ & $53(36)$ & $5(8)$ & $x$ \\
\hline & \multicolumn{3}{|c|}{ Netherlands } & \multicolumn{3}{|c|}{ Finland } & \multicolumn{3}{|c|}{ Norway } \\
\hline & GII & $\mathrm{GCl}$ & GDP & GII & $\mathrm{GCl}$ & GDP & GII & $\mathrm{GCl}$ & GDP \\
\hline 2013 & $40.1(33)$ & $4.7(8)$ & 48679 & $44.2(23)$ & $4.1(44)$ & 41293 & $42.7(27)$ & $3.7(91)$ & 67051 \\
\hline 2014 & $49.4(29)$ & $4.8(8)$ & 48612 & $48.5(32)$ & $4(51)$ & 41463 & $49.9(26)$ & $3.7(81)$ & 66018 \\
\hline 2015 & $49.9(28)$ & $5(7)$ & 49551 & $49.5(29)$ & $4.1(45)$ & 42059 & $49(31)$ & $3.9(58)$ & 61713 \\
\hline 2016 & $49.8(41)$ & $5.1(7)$ & 50540 & $51.7(31)$ & $4.3(35)$ & 43346 & $51.4(35)$ & $3.9(57)$ & 58792 \\
\hline 2017 & $52.4(39)$ & $5.2(4)$ & $x$ & $53.9(34)$ & $4.1(45)$ & $x$ & $54.7(30)$ & $3.7(76)$ & $x$ \\
\hline
\end{tabular}

* In brackets are given places in the ranking of a particular country.

Source: Own study based on:(Global Competitiveness Index, 2013-2018), (The Global Innovation Index, 2013-2017) and(OECD).

THE INFLUENCE OF ECO-INNOVATION ON THE LEVEL OF ECONOMIC DEVELOPMENT The analysis should be completed by an assessment of the impact of eco-innovation using previously analysed sub-indices for economic development measured by the level of GDP per capita in selected European countries. Three types of econometric models were estimated: OLS, FE and RE (table 4-6). 5 cross-sectional data units were included in each model. In the first step, the OLS model was evaluated and the panel was diagnosed. 
Table 4

An econometric model of the impact of agricultural competitiveness indicators on the economy.

\begin{tabular}{|c|c|c|c|c|}
\hline Variable & Coefficient & Stand error & t-Studenta & Value $p$ \\
\hline Constanta & -19254.5 & 25600.8 & -0.7521 & 0.4603 \\
\hline GII & 977.472 & 282.918 & 3.455 & $0.0024^{* * *}$ \\
\hline $\mathrm{GCl}$ & 4531.91 & 4921.17 & 0.9209 & 0.3676 \\
\hline $\begin{array}{l}\text { The arithmetic mean of } \\
\text { the dependent variable }\end{array}$ & 48362.46 & & $\begin{array}{l}\text { Standard deviation of } \\
\text { dependent variable }\end{array}$ & 13141.73 \\
\hline $\begin{array}{l}\text { The sum of residual } \\
\text { squares }\end{array}$ & $2.50 e+09$ & & $\begin{array}{l}\text { Standard error of } \\
\text { residues }\end{array}$ & 10914.90 \\
\hline R-squared coefficient & 0.370166 & & Adjusted R-square & 0.310182 \\
\hline
\end{tabular}

Designation: *** - means statistical significance at the level of 0.01 (1\%).

$\mathrm{GCl}$ - costs of agricultural policy

GII - sustainable ecological development

Both analysed ratios according to theoretical assumptions explained in the first part on the basis of endogenous growth models positively influenced changes in GDP per capita. However, the global innovation indicator turned out to be statistically significant. The low level of the model's explanation also suggested its correction. At the second stage of the analysis, the diagnosis of the panel model and the evaluation of the Breuch-Pagan test were made. Test statistic: $L M=17.2917$ with $p$ value $=$ prob (chi-square $(1)>17.2917)=3.20582 \mathrm{e}-005$. A low $\mathrm{p}$ value means rejecting the $\mathrm{HO}$ hypothesis that the MNK panel model is correct, against the $\mathrm{H} 1$ hypothesis that the random effect model is more appropriate. Based on the diagnosis, two panel models were estimated: with random effects (RE) and fixed effects (FE).

Table 5

RE model of the impact of agricultural competitiveness indicators on the economy.

\begin{tabular}{|l|c|c|c|l|}
\hline \multicolumn{1}{|c|}{ Variable } & Coefficient & Standard error & t-Studenta & \multicolumn{1}{c|}{ Value $\boldsymbol{p}$} \\
\hline Constanta & -21894.2 & 21583.1 & -1.014 & 0.3104 \\
\hline Gll & 906.134 & 168.661 & 5.373 & $<0.0001^{\star * *}$ \\
\hline $\mathrm{GCl}$ & 6240.16 & 4476.88 & 1.394 & 0.1634 \\
\hline $\begin{array}{l}\text { The arithmetic mean of } \\
\text { the dependent variable }\end{array}$ & 48362.46 & & $\begin{array}{l}\text { Standard deviation of } \\
\text { dependent variable }\end{array}$ & 13141.73 \\
\hline $\begin{array}{l}\text { The sum of residual } \\
\text { squares }\end{array}$ & $2.54 \mathrm{e}+09$ & & Standard error of residues & 10740.77 \\
\hline
\end{tabular}

Designation: ${ }^{* * *}$ - means statistical significance at the level of $0.01(1 \%)$.

Table 6

FE model of the impact of agricultural competitiveness indicators on the economy.

\begin{tabular}{|l|c|c|c|c|}
\hline \multicolumn{1}{|c|}{ Variable } & Coefficient & Standard error & t-Studenta & \multicolumn{1}{c|}{ Value $\boldsymbol{p}$} \\
\hline Constanta & -23715.7 & 31451.9 & -0.7540 & 0.4928 \\
\hline Gll & 904.531 & 286.274 & 3.160 & $0.0342^{\star *}$ \\
\hline GCl & 6531.49 & 4310.66 & 1.515 & 0.2043 \\
\hline $\begin{array}{l}\text { The arithmetic mean of the } \\
\text { dependent variable }\end{array}$ & 48362.46 & & $\begin{array}{l}\text { Standard deviation of } \\
\text { dependent variable }\end{array}$ & 13141.73 \\
\hline $\begin{array}{l}\text { The sum of residual } \\
\text { squares }\end{array}$ & $5.47 \mathrm{e}+08$ & & Standard error of residues & 5672.078 \\
\hline LSDV R-square & 0.862311 & & Within R-square & 0.610527 \\
\hline
\end{tabular}

Designation: ${ }^{* \star *}$ - means statistical significance at the level of $0.05(5 \%)$.

Both presented panel models were in line with the OLS model. The quality of the model has been improved, especially with fixed effects (for LSDV R square, approx. 86\%). The directions of changes in coefficients have also been preserved. All models showed high statistical significance of the GII index, while the $\mathrm{GCl}$ index was negligible in each study. 


\section{CONCLUSION}

The theoretical considerations made it possible to show the relationship between innovations influencing economic growth through endogenous growth models. This approach allows the inclusion of qualitative changes and the external effects of eco-innovation and the process of their creation through the agricultural policy and infrastructural investments that increase the availability and efficiency of resource use. The use of eco-innovation in agriculture, in contrast to innovations that increase the use of natural resources, allows to maintain the path of economic growth in line with the paradigm of sustainable development. These innovations allow to limit the use of resources and omit the so-called trap of zero growth. They also use external effects, increasing the efficiency of production factors at the level of the entire economy.

The impact of eco-innovation on overall economic development made in the last part of the study clearly confirmed the existence of such dependence. The impact of sustainable ecological development (GII) on economic development was particularly clearly reflected. When adopting a model of permanent effects, characteristic for individual countries, but timevarying, the adjustment value measured with $\mathrm{R}^{2}$ was relatively high, which indicates that even with the adoption of a simplified measure of GDP per capita, the impact of implementing sustainable development principles at the sectoral level (in this case agriculture) is also important for the whole socio-economic system.

\section{REFERENCES:}

Agénor, P-R., Neanidis, K.C. (2015). Innovation, public capital, and growth. Journal of Macroeconomics, 44, pp. 257-262.

Aghion, P., Bloom N., Blundell, R., Griffith, R., Howitt, P. (2005). Competition and Innovation: An Inverted-U Relationship. The Quarterly Journal of Economics, 120(2), pp. 701-728.

Augustowski, Ł., Sługocki, W. (2016). The influx of greenfield foreign direct investments into Poland and the efficiency of Polish labor market in the time of economic crisis. In: J. Babiak, ed., Studies of economic and social processes : dilemmas of economic development of Poland and the European. Poznań - Środa Wlkp. : The Great Poland University of Social and Economics, pp. 111-124.

Bilbao-Osorio, B., Rodríguez-Pose, A. (2004). From R\&D to Innovation and Economic Growth in the EU, Growth and Change. Journal of Urban and Regional Policy, 35(4), pp. 22-24.

Delmer, D. P. (2005). Agriculture in the developing world: Connecting innovations in plant research to downstream applications. Proceedings of the National Academy of Sciences of the United States of America, 102(44), pp. 157-160.

Giejbowicz, E., Chlebicka, A. (2012). Wspieranie innowacyjności w ramach WPR: dotychczasowe doświadczeni i nowe propozycje legislacyjne. Fundacja Programów Pomocy dla Rolnictwa, Sekcja Analiz Ekonomicznych Polityki Rolnej, pp. 3-4.

Giljum, S., Lieber, M., Daranova, A. (2017). EU Eco-Innovation Index 2016, pp. 1-2.

Global Innovation Index. Analysis, [Online]. Available at: https://www.globalinnovationindex.org/analysis [access: 12.01.2018].

Górka M., Ruda M. (2012), Innowacje w gospodarstwach rolniczych województwa podkarpackiego, Nierówności Społeczne a Wzrost Gospodarczy, 29, pp. 127-128.

Graczyk, M., Kaźmierczak-Piwko, L. (2012). Rola ekoinnowacji w procesie zrównoważonego rozwoju regionu, Prace Naukowe Uniwersytetu Ekonomicznego we Wrocławiu, 244, pp. 147-157.

Gust-Bardon, I. N. (2012). Innowacja w myśli ekonomicznej od XVIII do XX wieku : analiza wybranych zagadnień. Acta Universitatis Nicolai Copernici. Ekonomia, 43(1), pp. 112-120.

Kałuża, H., Ginter, A. (2014). Innowacje w gospodarstwach rolniczych młodych rolników. Wrocław: Prace Naukowe Uniwersytetu Ekonomicznego, 361, pp. 89-94.

Kaźmierczak-Piwko, L. (2012). Determinanty działalności ekoinnowacyjnej przedsiębiorstw. Journal of Management and Finance,10(1), pp. 533-543.

Kułyk, P. (2013). Finansowe wsparcie rolnictwa w krajach o różnym poziomie rozwoju gospodarczego. Poznań: Wydawnictwo Uniwersytetu Ekonomicznego, pp. 10-11.

Mirkowska, Z. (2010). Innowacje i innowacyjna gospodarka a rolnictwo. Zagadnienia Ekonomiki Rolnej, 4(325), pp. 126-130.

Moschini, G. (2001). Economic Benefits and Costs of Biotechnology Innovations in Agriculture. lowa State University Digital Repository,CARD Working Papers, 311, pp. 4-6.

OECD: GDP database, [Online]. Available: https://data.oecd.org/gdp/gross-domestic-product-gdp.htm [access: 12.01.2018].

Reardon, T., Lu, L., Zilberman, D. (2017). Linking among innovation, food system, and technology adoption, with implications for food policy. Food policy, 4. 
Stuiver, M., Leeuwis, C., Ploeg, J.D. (2004). The Power of Experience: Farmers' Knowledge and Sustainable Innovations in Agriculture. In: Seeds of Transition Essays on novelty production, niches and regimes in agriculture, Wiskerke, J.S.C., van der Ploeg, J.D.Royal Van Gorcum, pp. 94-97.

Szamrej-Baran, I. (2012). Konkurencyjność gospodarki Polski na tle wybranych gospodarek Unii Europejskiej. Studia i Prace WNEiZ, 25, pp. 133-140.

Szostak, E. (2015). Inteligentne specjalizacje w rozwoju regionu. Studia Ekonomiczne, 209, pp. 212-214.

Tabaka, A. (2015). Innowacje w rolnictwie i na obszarach wiejskich. Olsztyn: Warmińsko-Mazurski Ośrodek Doradztwa Rolniczego w Olsztynie, pp. 6-11.

The Global Competitiveness Report 2015-2016.

Uppenberg, K. (2009). Innovation and economic growth. EIB Papers, 14(1), pp. 12-19.

van Es, H., Woodard, J. (2017). Innovation in Agriculture and Food Systems in the Digital Age. In: The Global Innovation Index 2017. Innovation Feeding the World, p. 99.

Wong, P. K., Ho, Y. P., Autio, E. (2005). Entrepreneurship, Innovation and Economic Growth: Evidence from GEM data. Small Business Economics, 24(3), pp. 336-341.

World Economic Forum 2013-2014,[Online]. Available at:

http://www3.weforum.org/docs/WEF_GlobalCompetitivenessReport_2013 [access: 12.01.2018].

World Economic Forum 2014-2015,[Online]. Available at:http://www3.weforum.org/docs/WEF_GlobalCompetitivenessReport_2014-15.pdf [access: 12.01.2018]. 